Canadian

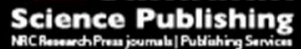

Canadian Journal of Forest Research Revue canadienne de recherche forestière

\title{
Genetic analysis of lodgepole pine (Pinus contorta) solid wood quality traits
}

\begin{tabular}{|r|l|}
\hline Journal: & Canadian Journal of Forest Research \\
\hline Manuscript ID & cjfr-2017-0152.R1 \\
\hline Manuscript Type: & Article \\
\hline Date Submitted by the Author: & 19 -Jun-2017 \\
\hline Complete List of Authors: & $\begin{array}{l}\text { Hayatgheibi, Haleh; Swedish University of Agriculture Sciences, Forest } \\
\text { Genetics and Plant Physiology } \\
\text { Fries, Anders; Swedish University of Agricultural Sciences, Department of } \\
\text { Forest Genetics and Plant Physiology } \\
\text { Kroon, Johan; The Forestry Research Institute of Sweden } \\
\text { Wu, Harry; Swedish University of Agriculture Sciences, Forest Genetics and } \\
\text { Plant Physiology; CSIRO, Plant Industry }\end{array}$ \\
\hline Keyword: & $\begin{array}{l}\text { Pinus contorta, Solid wood property, Genetic parameter, Early selection, } \\
\text { Genetic gain }\end{array}$ \\
\hline $\begin{array}{r}\text { Is the invited manuscript for } \\
\text { consideration in a Special } \\
\text { Issue? : }\end{array}$ & N/A \\
\hline \multicolumn{2}{|c}{} \\
\hline
\end{tabular}

\section{SCHOLARONE ${ }^{\text {" }}$}

Manuscripts 
1 Genetic analysis of lodgepole pine (Pinus contorta) solid wood quality traits

2

3

$4 \quad{ }^{1}$ Haleh Hayatgheibi, Anders Fries, and Harry X. Wu $(\nabla)$

5 Umeå Plant Science Centre, Department of Forest Genetics and Plant Physiology, Swedish University of

6 Agricultural Sciences, SE-90183 Umeå, Sweden, haleh.hayatgheibi@slu.se, anders.fries@slu.se,

7 harry.wu@slu.se

8

9

10

11

12

13

14

15

16

17

18

19

20

21

22
${ }^{2}$ Johan Kroon

Skogforsk Box 3. SE-918 21, Sävar, Sweden, Johan.Kroon@skogforsk.se

\footnotetext{
${ }^{3}$ Harry X. Wu

CSIRO NRCA, Black Mountain Laboratory, Canberra, ACT 2601, Australia, harry.w@csiro.au
}

Haleh Hayatgheibi ${ }^{1}$, Anders Fries ${ }^{1}$, Johan Kroon ${ }^{2}$ and Harry X. Wu ${ }^{1,3}$

(1)

2

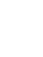

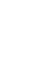

5

16

17




\section{Abstract}

24

1

Potential improvement of lodgepole pine (Pinus contorta Dougl. ex Loud. var. latifolia Engelm.) solid wood properties was examined by estimating age trends of inheritance, age-age genetic correlations and the efficiency of early selection using 823 increment cores sampled from 207 half-sib families at two independent progeny trials, aged 34-35 years, located in northern Sweden. High-resolution radial variation of annual ring width, wood density, microfibril angle (MFA) and modulus of elasticity (clearwood stiffness; $\mathrm{MOE}_{\mathrm{s}}$ ) was measured with SilviScan instrument. The dynamic stiffness $\left(\mathrm{MOE}_{\mathrm{tof}}\right)$ of standing trees was also obtained using Hitman ST300. Heritabilities ranged from 0.10 to 0.64 for growth and early-, transition- and latewood proportions, from 0.29 to 0.77 for density traits, and from 0.13 to 0.33 for MFA and stiffness traits. Genetic correlations between early age and the reference age (26 years) suggested that early selection is efficient at age 4 for MFA, and between ages 5 to 8 years for density and $\mathrm{MOE}_{\mathrm{s}}$. Unfavorable diameter-stiffness genetic correlations and correlated responses indicate that breeding for $1 \%$ increase in diameter would confer 5.5 and $2.3 \%$ decreases in lodgepole pine $\mathrm{MOE}_{\mathrm{s}}$ and $\mathrm{MOE}_{\text {tof }}$, respectively. Index selection with appropriate economical weights for growth and wood stiffness is highly recommended for selective breeding.

Key words: Pinus contorta, solid wood properties, early selection, genetic parameters, genetic gain

\section{5}


48

49

50

51

52

\section{Introduction}

Lodgepole pine (Pinus contorta Doug. Ex Loud. var. latifolia Engelm.) is a major component of coniferous forests in North America (Critchfield 1980), spanning widely from Yukon territory to California through British Columbia and Alberta in western Canada and USA (Critchfield 1957). In its natural habitat, lodgepole pine is ecologically a cornerstone species and renowned for its adaptation to harsh cold and dry conditions (Koch 1996). It is mainly used as saw-timber and pulp-wood production in western Canada. Due to its high tolerance to a wide range of environments and usable commercial products, it has been planted as an exotic species in many countries (Elfving et al. 2001), such as New Zealand (Ledgard 2001), Finland (Weissenberg 1972), Iceland (Sigurgeirsson 1988) and Sweden (Rosvall and Ericsson 1998).

In Sweden, early observations from small plantations of lodgepole pine between 1910 and 1930 indicated that this exotic species could be more productive than the native Scots pine (Pinus sylvesteris L.). The higher productivity has also been demonstrated in later studies, where 10-year-old lodgepole pine plus-trees were superior over Scots pine in terms of growth, survival and damage resistance (Ericsson 1993). The productivity of lodgepole pine was estimated to be $36 \%$ higher than that of Scots pine under comparable conditions (Elfving and Norgren 1993). Large-scale provenance tests were conducted during the 1960s and 1970s in order to select the adaptive populations for systematic planting and alleviate the predicted future shortage of timber in Sweden (Hagner 1971; Hagner 1983; Nellbeck 1981). A Swedish project to secure materials for breeding and utilization of lodgepole pine was initiated in the 1970's. Over one thousand plus-trees from 100 natural stands distributed in the interior of Yukon, British Columbia and Alberta were selected as the base breeding materials and open-pollinated seeds were collected from these selections (Bartram 1980; Ericsson 1993). Six preliminary breeding zones in northern Sweden were proposed based on latitude and elevation, mirroring similar climate regions and seed transfer zones in western Canada. Eighteen progeny trials were established in the 1980s as the first generation progeny trials for selection of next generation of breeding materials (Ericsson 1993).

Breeding materials for the second generation have mainly been selected based on growth, vitality and adaptive traits so far. Several studies estimated genetic parameters of growth, survival and form traits in Swedish lodgepole pine progeny trials (Ericsson and Danell 1995; Ericsson et al. 1994; Fries and 
Lindgren 1986). However, wood quality of lodgepole pine is a main issue in northern Sweden with higher frequency of stem sweep and breakage as compared to Scots pine (Hansson and Karlman 1997). This may be due to a larger foliage biomass (Norgren 1996), lower bending strength or lower modulus of elasticity of the stem (Andersson 1987; Fries et al. 2014). The larger crown size and more elastic stem of lodgepole pine than Scots pine might be the cause of more instability of lodgepole pine trees under the wind and snow load. Therefore, improvement of wood stiffness and crown structure using genetics and silviculture is an important step for a successful implementation of lodgepole pine plantation forests.

Among many wood properties affecting the stiffness and other end-use products, wood density is the most studied trait for a wide range of species (Zobel and Van Buijtenen 1989). Along with density, microfibril angle (MFA) has also been found to have a strong influence on stiffness (i.e., modulus of elasticity (MOE)) and strength of solid wood products (Cave 1976; Evans et al. 2000; Fries et al. 2014). Nevertheless, genetic parameters of MFA have been less well studied compared with density owing to the difficulty in measuring this trait (Kennedy et al. 2013). Due to the great variation of MFA within annual rings (Brändström 2002), MFA of large numbers of tracheids are needed to be measured to characterize its properties adequately (Gräns et al. 2009). Development of the SilviScan technology (Evans 1994) has enabled high-resolution measurement of radial variation and age trend analysis of genetic parameters for many solid wood properties in a wide range of species.

Several studies based on SilviScan measurement confirmed the influence of cambial age on inheritance and genetic control of wood properties and growth traits (Baltunis et al. 2007; Chen et al. 2014; Gräns et al. 2009; Hong et al. 2015; Lenz et al. 2010; Lenz et al. 2011). Narrow-sense heritability estimates of density in such studies were usually greater than those of MOE and MFA, and growth traits had the lowest heritability estimates. Additionally, high age-age genetic correlations observed for different wood traits suggested possible gains from early selection of wood quality traits. Correlation between growth traits and wood properties were also reported for several conifer species. Nearly, all estimated genetic correlations between density and growth traits were negative, particularly in radiata pine (Pinus radiata D. Don) (Baltunis et al. 2007; Gapare et al. 2009; Wu et al. 2008), Scots pine (Fries 2012; Hong et al. 2014), Norway spruce (Picea abies L. Karst.) (Chen et al. 2014) and White spruce (Picea glauca Moench.Voss.) (Lenz et al. 2011; Steffenrem et al. 2009). Due to such unfavorable correlation, it is of 
105

106

107

108

109

110

111

112

113

114

115

116

117

118

119

120

121

122

123

124

125

126

127

128

129

130

131

132

vital importance to investigate incorporation of wood quality traits as selection criteria in advanced breeding programs of lodgepole pine to ascertain future end-use products have appropriate properties (Wu et al 2007). To incorporate wood properties in lodgepole pine breeding program, genetic parameters such as age trends of heritability, genetic correlations and optimal early age selection should be examined.

The main focus of this study was to assess genetic parameters of solid wood traits, e.g. wood density, early wood and latewood proportion, MFA, clear wood stiffness and dynamic acoustic wood stiffness of standing trees of lodgepole pine in the Swedish progeny trials. Specific objectives were: 1) to quantify genetic variation and inheritance for growth and wood quality traits, 2) to estimate genetic and phenotypic correlations between growth and wood quality traits, 3) to estimate age-age genetic correlation and efficiency of early selection, and 4) to evaluate possible genetic gain using different selection criteria.

\section{Materials and methods}

\section{Study materials and measurements}

Two lodgepole pine progeny trials located in northern Sweden: Övra (Skogforsk S23F8060373; latitude $63^{\circ} 57^{\prime} \mathrm{N}$, longitude $16^{\circ} 46^{\prime} \mathrm{E}$ ) and Lagfors (Skogforsk S23F7960; latitude 62 $45^{\prime} \mathrm{N}$, longitude $17^{\circ} 08^{\prime}$

E) were selected for this study. Trial and sampling details are presented in Table 1. Övra was planted in 1980 with 178 open-pollinated families, originating from 4 geographic regions (provenances) (Fort Nelson, Watson Lake, Fort St. John and Prince George). Lagfors was planted in 1979 with 214 openpollinated families, originating from 2 provenances (Fort St. John and Prince George). There were no common families between the two trials. These families at both trials were planted in a randomized complete block (RCB) design. Each family was represented by 10 trees planted in a row with 5 replicates, resulting in 50 planted trees per family. Tree spacing was $2 \mathrm{~m}$ between rows and $1.5 \mathrm{~m}$ within rows. Bark-to-bark increment cores were sampled and acoustic velocity (AV) on standing tree were measured in the summer of 2014, 34 and 35 years after planting, in Övra and Lagfors, respectively. A complete assessment of diameter at breast height (DBH), vitality, damages and general condition (i.e. double stem) was made on 4329 trees at Övra, and on 6289 trees at Lagfors, aged 34 and 36 years, respectively. Doubled-stem was scored as 1 for trees with a double stem below their breast height (1.3 
133

134

135

136

137

138

139

140

141

142

143

144

145

146

147

148

149

150

151

152

153

154

155

156

157

158

159

160

m) and 0 otherwise. A total of 399 trees were sampled at Övra, at age 34 (approximately four trees from 100 families), while 424 trees, at age 35 (approximately four trees from 107 families) were sampled at Lagfors.

\section{SilviScan measurement}

A total of 399 trees were sampled at Övra (approximately four trees from 100 families), while 424 trees (approximately four trees from 107 families) were sampled at Lagfors. Bark-to-bark increment cores (12 millimeter in diameter) were collected at breast height of these 823 trees using an electronic boring machine and assessed by SilviScan instrument (Innventia AB, Stockholm, Sweden). As the orientation of family-rows differed at the two trials, samples were collected from the northern face of trees in Övra, while they were collected from eastern face of trees in Lagfors. Before the SilviScan measurement, each increment core was sawn into a 7-mm-high and 2-mm-thick radial strip from pith to the bark. Each sample was soaked in clean acetone to remove extractives causing disturbances of the measurement. Samples were air-dried overnight in the laboratory at approximately $23{ }^{\circ} \mathrm{C}$ and $43 \%$ relative humidity. The SilviScan system combines image analysis with X-ray absorption and X-ray diffraction to determine a high-resolution pith-to-bark radial variation for several important wood properties, such as wood density, MFA and MOE (Evans 2006).

Density was obtained as an average for $25 \mu \mathrm{m}$ radial intervals, while MFA was averaged over $2 \mathrm{~mm}$ intervals, and these estimates were used to predict MOE (Evans 2006). The widths, as well as the average wood density, MFA and MOE for each annual ring were determined. The three ring segments: earlywood (EW), transitionwood (TW), and latewood (LW) were identified from the wood density variation within each ring as follows: EW was defined as the part of the ring with wood density $0-20 \%$ of the span from minimum to maximum within the ring, LW as wood in the $80-100 \%$ span, and TW wood as in the $20-80 \%$ span. Based on these segments, earlywood density (EWD), transition wood density (TWD) and latewood density (LWD) were identified. Proportions of earlywood (EWP), transition wood (TWP) and latewood width (LWP) were also calculated. The cambial age at ring 26 (26 years) was used as a mature reference age, as most wood strips contained effective measurements for wood traits at cambial age 26 . 
161 The variation of wood properties from the SilviScan measurement was analysed for each annual ring 162 and at the whole core level. Since the area-weighted values are more accurate to represent the average properties of the wood (Gräns et al. 2009), the area-weighted value (AWV) for each trait was calculated and used in this study as follows

165

1) $\mathrm{AWV}=\frac{\sum\left(\alpha_{i} d_{i}\right)}{\sum \alpha_{i}}$

Where $\alpha_{i}$ is the cross sectional area of the $\mathrm{i}$ th annual ring assuming that each ring is circular and $d_{i}$ is the value of the ith annual ring (Hannrup et al. 2000).

\section{Acoustic velocity measurement}

A total of 1250 trees from 100 families at Övra and 1332 trees from 115 families at Lagfors were selected to measure dynamic MOE of lodgepole pine. The Hitman ST300 tool (Fiber-gen, Christchurch; New Zealand) was used to measure the acoustic velocity (AV) of standing-trees by inserting two sensor probes (transmitter and receiver) into the outer wood of the tree with the lowest probe around 1 meter high. Probes were placed in sections of stem that had fewer branches and vertically aligned at a distance of about 70 to $110 \mathrm{~cm}$ apart. The distance was measured with a laser beam and an acoustic wave was passed through the stem by striking the transmitter probe with a steel hammer. The wave was picked up by the receiver probe and its time-of-flight (tof) was recorded. Two series of eight hits were taken per tree and average value of two measurements was taken. Dynamic $\mathrm{MOE}\left(\mathrm{MOE}_{\mathrm{tof}}\right)$ can be estimated using the AV according to the Young's equation (Wang et al. 2001):

Where $\rho$ is the green density $\left(\mathrm{kg} . \mathrm{m}^{-3}\right)$ (Bucur 2006) and $V$ is the velocity of the wave (m. $\left.\mathrm{s}^{-1}\right)$. A constant green density of $1000 \mathrm{~kg} \mathrm{~m}^{-3}$ is normally used for calculating dynamic MOE in standing trees (Lenz et al. 2013).

\section{Statistical analysis}

All of the wood properties (density, MOE, MFA) and growth (DBH, ring width, EWP, TWP, and LWP) traits were analyzed in ASReml statistical software package (Gilmour et al. 2009) using linear mixedeffects model for individual sites. Additionally, bivariate analyses were used to estimate the genetic correlation between traits. The following model was used to estimate variance and covariance components for genetic parameters: 
189

190

191

192

193

194

195

196

197

198

199

200

201

202

203

204

205

206

207

208

209

210

211

212

3) $\quad y_{j k l m}=\mu+P_{k}+B_{j}+F_{l(k)}+B F_{j l(k)}+e_{j k l m s}$

where $\mathrm{y}$ is the vector of observation on the $m$ th tree from the $l$ th family within the $k$ th provenance in the $j$ th block, $\mu$ is the overall mean, and $P_{k}$ and $B_{j}$ are the fixed effects of the $k$ th provenance and the $j$ th block, respectively. The variable $F_{l(k)}$ is the random effect of the $l$ th family within the $k$ th provenance and $B F_{j l(k)}$ is the random interactive effect of the $j$ th block and the /th family within the $k$ th provenance and $e_{j k l m}$ is the random residual effect. In order to examine the effect of the double stem on the DBH trait, this variable was included in the model as a fixed effect of the doubled-stem covariate when it was significant at alpha $=0.05$.

Estimates of heritability were obtained for each trait at each trial using the variance components from the univariate single-site analysis. Standard errors were estimated using the Taylor series expansion method (Gilmour et al. 2009). The individual-tree narrow-sense heritability $\left(h_{i}{ }^{2}\right)$ for each trait at each trial was calculated using the following equation assuming these open-pollinated family are half-sib families (Falconer and Mackay 1996):

4) $\quad h_{i}^{2}=\frac{\widehat{\sigma}_{A}^{2}}{\widehat{\sigma}_{P}^{2}}=\frac{4 \times \widehat{\sigma}_{f}^{2}}{\hat{\sigma}_{f}^{2}+\widehat{\sigma}_{b f}^{2}+\widehat{\sigma}_{e}^{2}}$

where $\hat{\sigma}_{A}^{2}$ is the additive genetic variance, $\hat{\sigma}_{f}^{2}$ is among family variance, $\hat{\sigma}_{b f}^{2}$ is the family by block variance and $\hat{\sigma}_{e}^{2}$ is the residual variance. Genetic and phenotypic correlations (type A) between traits $\mathrm{x}$ and $\mathrm{y}\left(r_{(x, y)}\right)$, and also age-age genetic correlations were calculated using the following model:

$$
\text { 5) } \quad r_{(x, y)}=\frac{\widehat{\operatorname{cov}_{(x, y)}}}{\sqrt{\widehat{\sigma}_{(x)}^{2} \times \widehat{\sigma}_{(y)}^{2}}}
$$

where $\widehat{\operatorname{Cov}}_{(x, y)}$ is the estimated phenotypic or genetic covariance between traits $\mathrm{x}$ and $\mathrm{y}$ or between early age and reference age (ring 26). $\hat{\sigma}_{(x)}^{2}$ is the estimated additive genetic variance for trait $\mathrm{x}$ or for early age and $\hat{\sigma}_{(y)}^{2}$ is the estimated additive genetic variance for trait y or for the reference age.

The efficiency of early age selection $\left(E_{g e n}\right)$ relative to reference age for each trait $\left(E_{g e n}\right)$ is calculated as:

6) $E_{\text {gen }}=r_{A} \frac{i_{E} h_{E}}{i_{A} h_{A}}$ 
213

214

215

216

217

218

219

220

221

222

223

224

225

226

227

228

where $i_{E}$ is the selection intensity at the early age and $i_{A}$ is the selection intensity at the reference age. $h_{E}$ is the square root of heritability at the early age and $h_{A}$ is the square root of heritability at the reference age, and $r_{A}$ is the additive genetic correlation between the early and the reference ages. The same selection intensity for the early and the reference age was used in this calculation. In lodgepole pine breeding program, wood stiffness and growth are the main breeding objective traits. Therefore, genetic gains $\left(G_{i}\right)$ were calculated to improve growth and stiffness traits $\left(\mathrm{DBH}, \mathrm{MOE}_{\mathrm{s}}\right.$ and $\left.\mathrm{MOE}_{\mathrm{tof}}\right)$ by direct selection and indirect selection using correlated traits. The genetic gain expressed as percentage in direct selection of trait $i$ was estimated as:

7) $\Delta G_{i}=i \times h_{i}^{2} \times C V_{i}$

where $i$ is the selection intensity of $1 \%(i=2.67), h_{i}^{2}$ is the narrow-sense heritability of the trait and $C V$ is the coefficient of variation of the phenotypic effect (calculated as the phenotypic standard deviation devided by the mean of the specific trait). The correlated response of the target trait $t$ based on indirect selection of correlated trait i, was calculated as:

8) $C R_{t}=i \times h_{i} \times h_{t} \times r_{A} \times C V_{t}$

where $i$ is the selection intensity of $1 \%(i=2.667), h_{i}$ and $h_{t}$ are the square root of narrow-sense heritability for the selected trait and the target trait, respectively. $r_{A}$ is the additive genetic correlation between the traits and $C V_{t}$ is the phenotypic coefficient of variation for the target trait $t$.

\section{Results}

\section{Phenotypic trend for growth and wood quality traits}

Trees in Övra grew faster and had higher MFA than those in Lagfors. In contrast, area-weighted wood densities, $\mathrm{MOE}_{\mathrm{s}}$ and $\mathrm{MOE}_{\text {tof }}$ were higher in Lagfors (Table. 2). Trees originated from Watson Lake provenance had the highest density while trees originated from Fort Nelson provenance had the lowest density in Övra. Results showed that the geographic region was a highly significant source of variation of wood density $(P<0.001)$ in Övra, whereas it was non-significant in Lagfors. Overall age trends for growth and wood quality traits were approximately similar at both trials (Fig.1). Age trends of ring width at both trials peaked about annual ring 5 then declined towards the bark and stabilized at about ring 19. Density at early ages changed little, but increased from about ring 8 to the ring 18 in Övra and to 19 in Lagfors, then stabilized towards the bark. However, density was greater in Lagfors after ring 11. 
241 MFA gradually dropped from $40^{\circ}$ at ring 1 to about cambial age of 18 years for both trials and then

242 stabilized at $13^{\circ}$ and $10^{\circ}$ towards the bark in Övra and Lagfors, respectively. In contrast, MOE increased

243 from about $3 \mathrm{GPa}$ for both trials to about 13 and $17 \mathrm{GPa}$ close to the bark in Övra and Lagfors,

244 respectively. Övra showed a slow decrease in MOE and increase in MFA moving from ring 12 towards

245 the bark.

246 The proportion of latewood continuously increased from early age to the reference age of 26 years,

247 while the proportion of earlywood increased initially, then declined after the cambial age of 14 years.

248 Coefficients of variation (CV) varied from 6.8 to $27.9 \%$ in Övra and from 5.9 to $23.8 \%$ in Lagfors

249 (Table. 2). Among the growth traits, diameter at breast height had the greatest CV (24.5\% in Övra and

$25021.7 \%$ in Lagfors) and earlywood proportion had the lowest CV (10.5\% in Övra and 8.5\% in Lagfors).

251 Density traits had the lowest CV (6.9 to $8.11 \%$ in Övra and 5.9 to $7.0 \%$ in Lagfors) whereas MOE (21\%

252 in Övra and $15.8 \%$ in Lagfors) and MFA (27.9\% in Övra and $23.8 \%$ in Lagfors) had the greatest CV.

253 Trend for heritability

254 Narrow-sense individual heritability estimates obtained from cumulative ring width, area-weighted

255 wood density, MOE and MFA from annual ring 1 to annual ring 26 are presented in Fig. 2. Heritability

256 of ring width in Övra increased steadily from a very low value near the pith and stabilized at around 0.3

257 towards the bark. In contrast, heritability of ring width in Lagfors was greater near the pith (around 0.4

258 from ring 1 to ring 6) and then decreased continuously to about zero after ring 20 towards the bark.

259 Heritability for density fluctuated around the first three years near the pith in both trials and then

260 increased to the cambial age of 10 years with a peak of 0.6 in Övra and 0.9 in Lagfors. After that, the

261 heritability declined towards the bark. Heritability for MFA in Lagfors was greater than in Övra near the

262 pith, but converged to about 0.4 after the cambial age 8 at both trials. Heritability for MOE in Övra

263 increased from 0.2 near the pith to 0.4 at ring 14 with some decrease towards the bark after age 20

264 years, whereas heritability for MOE in Lagfors was greater near the pith (around 0.5 from ring 2 to ring

265 6) and then declined steadily and stabilized to 0.2 towards the bark.

266 Correlations between growth traits and wood quality traits

267 Genetic and phenotypic correlations calculated for growth, area-weighted wood density, MFA, and

268 stiffness traits are presented in Table 3. Genetic and phenotypic correlations between pairs of traits were

269 similar at both trials, except for the genetic correlation of MFA with wood density and growth traits. For 
270

271

272

273

274

275

276

277

278

279

280

281

282

283

284

285

286

287

288

289

instance, in Övra, most genetic correlations were low positive or negative between MFA and wood density traits, whereas such correlations were positive in Lagfors $(0.50,0.61,0.54$ and 0.25 for density, EWD, TWD and LWD, respectively). Genetic correlations for MFA with EWP, TWP and LWP were greater in Lagfors than in Övra. Likewise, genetic correlation of $\mathrm{MOE}_{\mathrm{s}}$ with EWP, TWP and LWP differed considerably between the two trials.

As expected, there were high positive genetic correlations among the four wood density traits at both trials. Furthermore, genetic correlation between the two stiffness measurements $\left(\mathrm{MOE}_{\mathrm{s}}\right.$ and $\left.\mathrm{MOE}_{\mathrm{tof}}\right)$ was high (0.91 and 0.90 in Övra and Lagfors, respectively) and stiffness had high and positive correlation with wood density traits at both trials. Similarly, stiffness had moderate to high negative genetic correlation with MFA (-0.75 and -0.67 in Övra, and -0.68 and -0.43 in Lagfors, for $\mathrm{MOE}_{\mathrm{s}}$ and $\mathrm{MOE}_{\text {tof }}$, respectively).

Genetic correlations of DBH with wood density and stiffness $\left(\mathrm{MOE}_{\mathrm{s}}\right.$ and $\left.\mathrm{MOE}_{\text {tof }}\right)$ were negative at both trials. Genetic correlation of DBH with wood density traits ranged from -0.06 to -0.53 in Övra while it ranged from -0.31 to -0.68 in Lagfors. In Övra, genetic correlations between DBH and stiffness traits varied from -0.35 to -0.51 while they varied from -0.14 to -0.80 in Lagfors. In general, DBH had greater negative genetic correlation with wood density and $\mathrm{MOE}_{\mathrm{s}}$ in Lagfors. Genetic correlations of EWP with all wood density and stiffness traits were negative at both trials except for genetic correlations of EWP with both LWD and $\mathrm{MOE}_{\mathrm{s}}$ in Lagfors. Genetic correlation of TWP with density traits was low to moderate positive except for correlation with LWD, which was low to moderate negative at both trials. Similarly, genetic correlation of LWP with all density traits was moderate to high positive at both trials. Standard errors of genetic correlations were relatively large, particularly for correlations involving MFA and $\mathrm{MOE}_{\mathrm{s}}$ with other traits at both trials. This might be due to small sample size of each family.

\section{Age-age correlation}

Age-age genetic correlations between each of the rings and the reference ring at age 26 years were calculated for cumulative ring width, wood density, MOE and MFA (Fig. 3). The age-age genetic correlations were very high and reached 0.9 from ring 8 onwards for all studied traits at both trials. The age-age genetic correlation at earlier ages was higher in Lagfors for cumulative ring width, whereas it was lower for wood density and MFA. The genetic correlation of ring width was unusually high in Lagfors, above 0.8 from ring 1 , while it reached 0.8 at ring 4 in Övra. For wood density in Lagfors, the 
299

300

301

302

303

304

305

306

307

308

309

310

311

312

313

314

315

316

317

318

319

320

321

322

323

324

325

genetic correlation reached 0.8 at ring 6 while it was around 0.8 already from ring 1 in Övra. The ageage genetic correlations for MOE and MFA were very similar at both trials, and MFA had the highest genetic correlation at earlier ages among the wood quality traits at both trials.

\section{Early selection efficiency}

Efficiency of early selection relative to selection based on the reference ring 26 calculated for cumulative ring width, area-weighted wood density, MOE and MFA is shown in Fig. 4. Early selection efficiency for ring width in Övra was low from ring 1 and increased steadily towards the bark until it reached around 0.8 at the reference ring 26 . Such efficiency was calculated only for Övra as the heritability of ring width in Lagfors was very low and reached zero at the reference ring 26 . Early selection efficiencies were very high for wood density, MFA and MOE. Early selection efficiency for wood density was greater at Övra than in Lagfors, as efficiency in Övra reached 1 from the first rings, while such efficiency was achieved at ring 10 in Lagfors. This is mainly due to the higher age-age genetic correlation at early ages in Övra. Early selection for MFA was already at age 3 as efficient as selection at the reference ring 26 at both trials. Early selection efficiency for MOE was greater at earlier ages in Lagfors and peaked to higher than 1.5 at about ring 10, then declined gradually and stabilized to around 1 towards the bark. Such efficiency in Övra was very low at earlier ages, then increased steadily and reached 1 at about ring 10. This is mainly due to the lower heritability at earlier ages in Övra.

\section{Genetic gains and response to selection}

Combined-site genetic gains $(\Delta \mathrm{G})$ from the direct selection on three breeding objective traits (DBH, $\mathrm{MOE}_{\mathrm{s}}$ and $\left.\mathrm{MOE}_{\mathrm{tof}}\right)$ and correlated genetic gains $\left(C R_{t}\right)$ from the indirect selection based on growth and wood stiffness traits with a $1 \%$ selection intensity $(i=2.67)$ are presented in Table 4 . The genetic gains observed for direct traits were moderate (e.g. $\Delta G_{D B H}=7.9 \%, \Delta G_{M O E_{S}}=13 \%$ and $\Delta G_{M O E_{t o f}}=12.7 \%$ ).

As expected, due to the negative genetic correlation of growth with $\mathrm{MOE}_{\mathrm{s}}$ and $\mathrm{MOE}_{\text {tof }}$, selection based on $\mathrm{DBH}$ generated negative genetic gains for $\mathrm{MOE}_{\mathrm{s}}(-5.5 \%)$ and $\mathrm{MOE}_{\text {tof }}(-2.3 \%)$. Similarly, due to the negative genetic correlation of MFA with $\mathrm{MOE}_{\mathrm{s}}$ and $\mathrm{MOE}_{\text {tof }}$, selection for reduced MFA resulted in correlated responses for higher $\mathrm{MOE}_{\mathrm{s}}(9.6 \%)$ and $\mathrm{MOE}_{\text {tof }}(8.0 \%)$.

\section{Discussion}


326

327

328

329

330

331

332

333

334

335

336

337

338

339

340

341

342

343

344

345

346

347

348

349

350

351

352

353

354

Similar to other early conifer breeding programs, wood quality traits were not included as selection criteria or breeding objective traits in first generation selection of Swedish lodgepole pine breeding program (Ericsson and Danell 1995; Wu et al. 2008). In northern Sweden, improvement of wood properties is even more urgent, mainly due to the impact of snow pressure, which causes stem bending and stem breakage (Fries et al. 2014). Genetic parameters for wood quality traits have not been previously estimated for lodgepole pine. The focus of this study was mainly to evaluate the degree of genetic control for important solid wood properties, such as wood density, MFA and MOE from pith-tobark at two genetically independent progeny trials of lodgepole pine in Sweden. Most wood properties and their genetic controls change with cambial age and stabilize only with cambial maturity (Hannrup and Ekberg 1998; Lenz et al. 2010). In general, wood density and MOE increase, and MFA decreases as trees become older, and such changes ensure that end-use products have desirable wood characteristics (Dungey et al. 2006). Higher MFA and lower MOE in rings near the pith was hypothesized to ensure flexibility of young stems and protect them from wind damage (Hong et al. 2015; Lenz et al. 2010)

\section{Mean values and site effect}

Phenotypic trends observed for solid wood properties in this study were similar to those of other conifers, such as radiata pine (Dungey et al. 2006; Wu et al. 2007), Scots pine (Hong et al. 2015), Norway spruce (Chen et al. 2014; Gräns et al. 2009) and black spruce (Picea mariana (Mill.) (Alteyrac et al. 2007). Density and MOE were higher, while MFA was lower in rings near the pith, and then density and MOE increased, while MFA decreased and all properties stabilized with cambial maturity at both trials. The age trends observed for ring density were also consistent with previous reports in lodgepole pine as annual ring density dropped initially to a minimum in rings 6 to 10 , and then increased to a maximum towards the bark (Taylor et al. 2007). Phenotypic trends observed for density and LWP were similar, as both traits increased steadily from the pith towards the bark.

Observation of relationship between growth and wood properties among sites usually indicate that the site of higher fertility (higher growth rate) produces trees with lower wood density and lower stiffness (Baltunis et al 2007; Wu et al 2007; Gapare et al 2010; Chen et al 2014). The two progeny trials investigated in this study were genetically different; however, their phenotypic trends observed for most traits were generally identical. Density, MOE and LWP were higher, while the growth rate and MFA were lower in Lagfors. Wood density and LWP decreased, while ring width increased (faster growth), 
355

356

357

358

359

360

361

362

363

364

365

366

367

368

369

370

371

372

373

374

375

376

377

378

379

380

381

382

after age 18 years in Övra. Similarly, such decreases in wood density and LWP, associated with faster growth, have previously been reported for white spruce (Park et al. 2012).

\section{Genetic parameters}

Heritability estimates of area-weighted densities (Density, EWD, LWD and TWD) obtained for the current lodgepole pine study were comparable with other coniferous species. Such estimates for MFA (0.30 in Övra, 0.33 in Lagfors) and $\mathrm{MOE}_{\mathrm{s}}$ (0.30 in Övra, 0.13 in Lagfors) were lower than those reported in radiata pine ( 0.61 and $0.50, \mathrm{Wu}$ at al. (2008)), but similar to Scots pine ( 0.26 and 0.37 , Hong et al. (2014)) and Norway spruce (0.15 and 0.33, Chen et al., (2015)). Area-weighted densities and ring width proportions (EWP, TWP and LWP) had greater heritability estimates than those of MFA and stiffness $\left(\mathrm{MOE}_{\mathrm{s}}\right.$ and $\left.\mathrm{MOE}_{\mathrm{tof}}\right)$. This observation agree with estimates in other conifers (Baltunis et al. 2007; Chen et al. 2014; Hong et al. 2014). In general, standard errors of heritability estimates in this study were high, particularly for $\mathrm{MOE}_{\mathrm{s}}$ and MFA measured with SilviScan. This might be due to compression wood, which affects heritability estimates for wood quality traits (Donaldson 2008). Additionally, fewer number of sampled trees (e.g. 4 trees) per family in the current study than most other studies (5-12 trees) using SilviScan, might have incurred high standard errors. For future investigations, selection of more than 4 trees per family is desirable.

Unfavorable genetic correlations between wood density and growth traits is often reported (Zobel and Van Buijtenen 1989) and strong adverse genetic correlations are usually observed in conifers (Fries 2012; Rozenberg and Cahalan 1997). Wu et al. (2008) summarized radiata pine studies and observed an average negative genetic correlation of -0.48 between wood density and DBH. Negative genetic correlations between growth and wood density were also observed in Scots pine (-0.48) and Norway spruce (-0.60) (Hong et al. 2014; Chen et al. 2014). These studies also reported stronger negative genetic correlations between growth and stiffness. Similarly, genetic correlation of DBH with density (0.24 in Övra and -0.31 in Lagfors), $\mathrm{MOE}_{\mathrm{s}}\left(-0.51\right.$ in Övra and -0.80 in Lagfors), and $\mathrm{MOE}_{\text {tof }}(-0.35$ in Övra and -0.14 in Lagfors) were unfavorable in this study. Therefore, tree breeders must consider this unfavorable genetic correlation in designing breeding programs. There are several methods reported in dealing with such adverse correlations, including estimating economic weights to improve growth and wood quality traits simultaneously (Ivkovic et al. 2010), designing effective breeding strategies (Wu and 
383

384

385

386

387

388

389

390

391

392

393

394

395

396

397

398

399

400

401

402

403

404

405

406

407

408

409

410

411

Sanchez 2011; Yanchuk and Sanchez 2011; Hallingback et al. 2014), and using index selection such as restricted index (Chen et al. 2016)

In conifers, MFA varies significantly from pith to bark (Donaldson 2008) and such great within-tree variation hinders accurate measurement of MFA properties in trees (Brändström 2002), and therefore, MFA of large numbers of tracheids are needed to be measured to obtain accurate MFA values in trees (Gräns et al. 2009). Additionally, the relationship between MFA and density is a controversial subject in the literature as it varies within and among species (Baltunis et al. 2007; Donaldson 2008). Such correlation was negative in Scots pine, radiata pine and Norway spruce (Chen et al. 2014; Dungey et al. 2006; Hong et al. 2014), whereas Bergander et al. (2002) found no correlation between MFA and density in Norway spruce (Bergander et al. 2002). In this study, we found a low to moderate positive correlation between MFA and density associated with high standard errors. In white spruce, Lenz et al. (2011) also found a high to moderate correlation between density and MFA in rings near the pith and hypothesized that both traits could be genetically linked during formation of juvenile wood (Lenz et al. 2011). Strong negative (but favorable) correlation between MOE and MFA obtained in this study agree well with findings in other conifers (Baltunis et al. 2007; Cave and Walker 1994; Chen et al. 2014) and indicate that selection for reduced MFA would produce gains in MOE and overall improvement of lodgepole pine stiffness.

\section{Early selection efficiency}

There is usually a transition from juvenile to mature wood phases for wood properties from pith to bark in pine species (Burdon et al. 2004; Loo et al. 1985). Juvenile wood generally has lower quality when compared to mature wood (Wang and Stewart 2012). Therefore, improvement of juvenile wood is highly important. Besides the juvenile wood, the whole core wood can be improved through early selection if there is a high age-age genetic correlation. Age-age genetic correlations and efficiency of early age selection of lodgepole pine were examined. Age-age genetic correlations from early ages to the reference age of 26 years for wood density, MFA and MOE were very high in this study, which implies that early selection for wood quality traits is highly efficient if heritability at early ages were comparable or higher than later ages. In this study, MFA had the most potential for early age selection, as efficiency reached the unity at ring 4 at both trials. Similarly, in white spruce and Norway spruce, MFA was the most potential trait for selection as early as ring 4 (Chen et al. 2014; Lenz et al. 2011). 
412 Several investigations in conifers, such as radiata pine ( $\mathrm{Li}$ and $\mathrm{Wu} 2005$; Wu et al. 2007), Scots pine

413 (Hong et al. 2015), white spruce (Lenz et al. 2011) and Norway spruce (Chen et al. 2014) revealed that

414 early selection is more efficient in wood quality traits than in growth traits. This is due to the higher

415 heritability and higher age-age correlation of wood quality traits compared to growth traits. Results of

416 this study showed that early selection at age 3 for wood density and MFA, and at age 10 for MOE was

417 as efficient as the reference age in Övra. Similarly, early selection at age 3 for MFA and MOE, and at

418 age 9 for wood density was as efficient as the reference age 26 in Lagfors. Lower efficiency of early age

419 selection for MOE in Övra and for wood density in Lagfors are due to lower heritability and lower age-

420 age correlation found in these traits.

421 Genetic gains

422 As the breeding program of lodgepole pine progresses, it becomes more vital to incorporate solid wood

423 properties, i.e. stiffness, as main selection criteria in advanced generations of Swedish lodgepole pine.

424 The expected genetic gains obtained for stiffness, if selection was made only based on $\mathrm{MOE}_{\mathrm{s}}$ and

$425 \mathrm{MOE}_{\text {tof }}$, were about $13.0 \%$. However, due to the unfavorable genetic correlation between growth and

426 stiffness, selection for $1 \%$ increase in DBH would result in 5.5 and $2.3 \%$ decreases in $\mathrm{MOE}_{\mathrm{s}}$ and

$427 \quad \mathrm{MOE}_{\text {tof }}$, respectively.

\section{Conclusion}

429 1. Wood density, $\mathrm{MOE}_{\mathrm{s}}$, and LWP increased from the pith, while MFA and ring width were high around 430 the pith then gradually decreased and stabilized towards the bark. In general, radial age trends were 431 similar at both trials, though stiffness and LWP were greater, whereas ring width was lower in Lagfors, 432 after the 18 years of cambial age.

433 2. Inheritance pattern of wood density was very similar at both trials and heritability reached the 434 maximum value of about 0.6 in Övra and 0.9 in Lagfors between ages 6 to 14 years of cambial age.

435 Ring width, $\mathrm{MOE}_{\mathrm{s}}$ and MFA were more heritable in Lagfors around the pith. However, heritability 436 estimates of ring width reached zero near the bark in Lagfors, while it reached around 0.2 in Övra. 437 Heritability estimate of $\mathrm{MOE}_{\mathrm{s}}$ and MFA reached around 0.2 and 0.3 , respectively at both trials. 
438 3. Genetic correlations between the early age and the reference age of 26 years were very high $(\sim 0.8$

439 after age 5), suggesting that early selection is efficient at age 4 for MFA, and between ages 5 to 8 years

440 for density and $\mathrm{MOE}_{\mathrm{s}}$.

441 4. Adverse genetic correlations between growth and wood quality traits were found in this study.

442 Breeding for $1 \%$ increase in growth (diameter) would result in 5.5 and $2.3 \%$ decreases in lodgepole pine

443 stiffness $\left(\mathrm{MOE}_{\mathrm{s}}\right.$ and $\left.\mathrm{MOE}_{\text {tof }}\right)$, respectively. Therefore, index selection with appropriate economical

444 weights for growth and stiffness is highly recommended for breeding selection.

445 Acknowledgement

446 The authors gratefully acknowledge financial support from Föreningen Skogsträdsförädling, Bo Rydins,

447 Kempe foundations, and Swedish University of Agricultural Sciences (SLU). We would also

448 acknowledge Liming Bian, Zhiqiang Chen, David Hall and Zhou Hong for their assistance in field

449 sampling. 


\section{References}

Alteyrac, J., Cloutier, A., Ung, C.H., and Zhang, S. 2007. Mechanical properties in relation to selected wood characteristics of black spruce. Wood Fiber Sci. 38(2): 229-237.

Andersson E. 1987. Pinus contorta - Hållfasthet [Pinus contorta - strength]. Department of Forest Products, Swedish University of Agricultural Sciences, Uppsala. Rep. 185. pp. 44. Swedish with English summary.

Baltunis, B.S., Wu, H.X., and Powell, M.B. 2007. Inheritance of density, microfibril angle, and modulus of elasticity in juvenile wood of Pinus radiata at two locations in Australia. Can. J. For. Res. 37(11): 2164-2174. doi: 10.1139/x07-061.

Bartram, V. 1980. Sweden initiates a large scale tree improvement and seed production program for Lodgepole pine. The Forestry Chronicle. 56(2): 63-66.

Bergander, A., Brändström, J., Daniel, G., and Sahnen, L. 2002. Fibril angle variability in earlywood of Norway spruce using soft rot cavities and polarization confocal microscopy. J. Wood Sci. 48(4): 255-263.

Brändström, J. 2002. Morphology of Norway spruce tracheids with emphasis on cell wall organisation. Doctoral thesis, Department of Wood Sciences. Acta Universitatis Agriculturae Sueciae, Swedish University of Agricultural Sciences, Uppsala, Sweden. Silvestria 237. ISBN 91-576-6321-1

Bucur, V. 2006. Acoustics of wood. 2nd ed. Springer, New York.

Burdon, R.D., Kibblewhite, R.P., Walker, J.C., Megraw, R.A., Evans, R., and Cown, D.J. 2004. Juvenile versus mature wood: a new concept, orthogonal to corewood versus outerwood, with special reference to Pinus radiata and P. taeda. For. Sci. 50(4): 399-415.

Cave, I., and Walker, J. 1994. Stiffness of wood in fast-grown plantation softwoods: the influence of microfibril angle. For. Prod. J. 44(5): 43-48

Cave, I.D. 1976. Modelling the structure of the softwood cell wall for computation of mechanical properties. Wood Sci. Technol. 10(1): 10-28. 
Chen, Z.-Q., Gil, M.R.G., Karlsson, B., Lundqvist, S.-O., Olsson, L., and Wu, H.X. 2014. Inheritance of growth and solid wood quality traits in a large Norway spruce population tested at two locations in southern Sweden. Tree Genet. Genomes, 10(5): 1291-1303.

Chen, Z.-Q., Karlsson, B., Lundqvist, S.-O., Gil, M.R.G., Olsson, L., and Wu, H.X. 2015. Estimating solid wood properties using Pilodyn and acoustic velocity on standing trees of Norway spruce. Ann. For. Sci. 72(4): 499-508.

Chen, Z.-Q, Karlsson, B., Morling, T., Olsson, L., Mellerowicz, E.J., Wu, H.X., Lundqvist, S.-O., and Gil, M.R.G. 2016. Genetic analysis of fiber dimensions and their correlation with stem diameter and solid wood properties in Norway spruce. Tree Genet. Genomes, 12(6): 123. doi: 10.1007/s11295-016-1065-0.

Critchfield, W.B. 1957. Geographic variation in Pinus contorta. Maria Moors Cabot Foundation, Publication No. 3. Harvard University, Cambridge, MA.

Critchfield, W.B. 1980. The genetics of lodgepole pine. U. S. For. Serv. Wash. Off. Res. Pap. WO-37

Donaldson, L. 2008. Microfibril angle: measurement, variation and relationships-a review. Iawa J. 29(4): 345-386.

Dungey, H.S., Matheson, A.C., Kain, D., and Evans, R. 2006. Genetics of wood stiffness and its component traits in Pinus radiata. Can. J. For. Res. 36(5): 1165-1178.

Elfving, B., Ericsson, T., and Rosvall, O. 2001. The introduction of lodgepole pine for wood production in Sweden — a review. For. Ecol. Manage. 141(1-2): 15-29. doi: http://dx.doi.org/10.1016/S0378-1127(00)00485-0.

Elfving, B., and Norgren, O. 1993. Volume yield superiority of lodgepole pine compared to Scots pine in Sweden. Department of Forest Genetics and Plant Physiology, Swedish University of Agricultural Sciences, Umeå, Sweden. Rep. 11. pp. 69-80.

Ericsson, T., and Danell, Ö. 1995. Genetic evaluation, multiple-trait selection criteria and genetic thinning of pinus contorta var. latifolia seed orchards in Sweden. Scand. J. For. Res. 10(1-4): 313-325.

Ericsson, T., Danell, Ö., and Andersson, B. 1994. Genetic variation of Pinus contorta var. latifolia breeding material in Sweden. Can. J. For. Res. 24(4): 723-729. 
Ericsson, T. 1993. Provenance qualities of the Pinus contorta breeding base in Sweden. Forestry Research Institute of Sweden, Uppsala. Report No. 4, 33 pp. ISBN 99-1843452-X.

Evans, R. 1994. Rapid measurement of the transverse dimensions of tracheids in radial wood sections from Pinus radiata. Holzforschung, 48(2): 168-172.

Evans, R. 2006. Wood stiffness by x-ray diffractometry. In Characterisation of the Cellulosic Cell Wall. Proceedings of the workshop, Grand Lake, Colorado, 25-27 August 2003. Southern Research Station, University of Iowa and the Society of Wood Science and Technology. Edited by D. Stokke and L. Groom. Blackwell Publishing, Ames, Iowa, USA. Chapter 11. pp. 1-8

Evans, R., Ilic, J., Matheson, C., Schimleck, L., and Blakemore, P. 2000. Rapid estimation of solid wood stiffness using SilviScan. In Proceedings of 26th Forest Products Research Conference, Research developments and industrial applications and Wood Waste Forum, Clayton, Victoria, Australia, 19-21 June 2000. CSIRO Forestry and Forest Products. pp. 49-50.

Falconer, D., and Mackay, T. 1996. Introduction to quantitative genetics. 4th edn., Longman, New York.

Fries, A. 2012. Genetic parameters, genetic gain and correlated responses in growth, fibre dimensions and wood density in a Scots pine breeding population. Ann. For. Sci. 69(7): 783-794. doi: $10.1007 / \mathrm{s} 13595-012-0202-7$.

Fries, A., and Lindgren, D. 1986. Performance of plus tree progenies of Pinus contorta originating north of latitude $55^{\circ} \mathrm{N}$ in a Swedish trial at $64^{\circ} \mathrm{N}$. Can. J. For. Res. 16(3): 427-437.

Fries, A., Ulvcrona, T., Wu, H.X., and Kroon, J. 2014. Stem damage of lodgepole pine clonal cuttings in relation to wood and fiber traits, acoustic velocity, and spiral grain. Scand. J. For. Res. 29(8): 764-776. doi: 10.1080/02827581.2014.978886.

Gapare, W.J., Baltunis, B.S., Ivković, M., and Wu, H.X. 2009. Genetic correlations among juvenile wood quality and growth traits and implications for selection strategy in Pinus radiata D. Don. Ann. For. Sci. 66(6): 1-9.

Gilmour, A.R., Gogel, B.J., Cullis, B.R., and Thompson, R. 2009. ASReml user guide release 3.0. VSN International Ltd., Hemel Hempstead, U.K. 
Gräns, D., Hannrup, B., Isik, F., Lundqvist, S.-O., and McKeand, S. 2009. Genetic variation and relationships to growth traits for microfibril angle, wood density and modulus of elasticity in a Picea abies clonal trial in southern Sweden. Scand. J. For. Res. 24(6): 494-503.

Hagner, S. 1971. Cultivation of Pinus contorta in northern Sweden. Swedish Forestry Association Journal 3: 219-246.

Hagner, S. 1983. Pinus contorta: sweden's third conifer. For. Ecol. Manage. 6(3): 185-199. doi: $10.1016 / \mathrm{s} 0378-1127(83) 80002-4$.

Hallingback, H.R., Sanchez, L., and Wu, H.X. 2014. Single versus subdivided population strategies in breeding against an adverse genetic correlation. Tree Genet. Genomes, 10(3): 605-617. doi: 10.1007/s11295-014-0707-3.

Hannrup, B., and Ekberg, I. 1998. Age-age correlations for tracheid length and wood density in Pinus sylvestris. Can. J. For. Res. 28(9): 1373-1379.

Hannrup, B., Ekberg, I., and Persson, A. 2000. Genetic correlations among wood, growth capacity and stem traits in Pinus sylvestris. Scand. J. For. Res. 15(2): 161-170.

Hansson, P., and Karlman, M. 1997. Survival, height and health status of 20-year-old Pinus sylvestris and Pinus contorta after different scarification treatments in a harsh boreal climate. Scand. J. For. Res. 12(4): 340-350.

Hong, Z., Fries, A., and Wu, H.X. 2014. High negative genetic correlations between growth traits and wood properties suggest incorporating multiple traits selection including economic weights for the future Scots pine breeding programs. Ann. For. Sci. 71(4): 463-472.

Hong, Z., Fries, A., and Wu, H.X. 2015. Age trend of heritability, genetic correlation, and efficiency of early selection for wood quality traits in Scots pine. Can. J. For. Res. 45(7): 817-825.

Ivkovic, M., Wu, H., and Kumar, S. 2010. . Bioeconomic modelling as a method for determining economic weights for optimal multiple-trait tree selection. Silvae Genet. 59(2-3): 77-90.

Kennedy, S., Cameron, A., and Lee, S. 2013. Genetic relationships between wood quality traits and diameter growth of juvenile core wood in Sitka spruce. Can. J. For. Res. 43(1): 1-6.

Koch, P. 1996. Lodgepole pine in North America. Forest products Society, Madison, Wisc.

Ledgard, N. 2001. The spread of lodgepole pine (Pinus contorta, Dougl.) in New Zealand. For. Ecol. Manage. 141(1-2): 43-57. doi: 10.1016/s0378-1127(00)00488-6. 
Lenz, P., Auty, D., Achim, A., Beaulieu, J., and Mackay, J. 2013. Genetic improvement of white spruce mechanical wood traits—early screening by means of acoustic velocity. Forests 4(3): 575-594.

Lenz, P., Cloutier, A., MacKay, J., and Beaulieu, J. 2010. Genetic control of wood properties in Picea glauca-an analysis of trends with cambial age. Can. J. For. Res. 40(4): 703-715.

Lenz, P., MacKay, J., Rainville, A., Cloutier, A., and Beaulieu, J. 2011. The influence of cambial age on breeding for wood properties in Picea glauca. Tree Genet. Genomes, 7(3): 641-653.

Li, L., and Wu, H.X. 2005. Efficiency of early selection for rotation-aged growth and wood density traits in Pinus radiata. Can. J. For. Res. 35(8): 2019-2029.

Loo, J.A., Tauer, C.G., and McNew, R.W. 1985. Genetic variation in the time of transition from juvenile to mature wood in loblolly pine (Pinus-taeda L). Silvae Genet. 34(1): 14-19.

Nellbeck, R. 1981. Growing of $P$. contorta. Programme and experiences 1968-1980, AB Iggesunds Bruk [Pinus contorta var. latifolia, lodgepole pine, provenances, type of seedling, planting time, soil preparation, stocking, thinning, predators, Sweden]. Sveriges Skogsvårdfoerbunds Tidskrift.

Norgren, O. 1996. Growth analysis of Scots pine and lodgepole pine seedlings. For. Ecol. Manage. 86(1-3): 15-26.

Park, Y.-S., Weng, Y., and Mansfield, S.D. 2012. Genetic effects on wood quality traits of plantationgrown white spruce (Picea glauca) and their relationships with growth. Tree Genet. Genomes, 8(2): 303-311.

Rozenberg, P., and Cahalan, C. 1997. Spruce and wood quality: Genetics aspects. Silvae Genet. 46: $270-279$

Rosvall, O., and Ericsson, T. 1998. Root components of containerized and gree-growing seedlings of Scots pine and lodgepole pine. In: Rotutveckling och stabilitet, konferens i Garpenberg, 30 September-1 October 1997. Redogörelse nr 7 1998, SkogForsk-Stiftelsen skogsbrukets forskningsinstitut, Uppsala, pp. 35-50.

Sigurgeirsson, A. 1988. Stafafura á Íslandi. Vöxtur, ástand og möguleikar [Pinus contorta Dougl. in Iceland: growth, condition and potential]. Ársrit Skógræktarfélags Íslands 1988, pp. 3-36. (summary in English) 
Steffenrem, A., Kvaalen, H., Høibø, O.A., Edvardsen, Ø.M., and Skrøppa, T. 2009. Genetic variation of wood quality traits and relationships with growth in Picea abies. Scand. J. For. Res. 24(1): 15-27. doi:10.1080/02827580802641215.

Taylor, F.W., Wang, E.I., and Micko, M.M. 2007. Differences in the wood of lodgepole pine in Alberta. Wood Fiber Sci. 14(4): 296-309.

Wang, M.L., and Stewart, J.D. 2012. Determining the transition from juvenile to mature wood microfibril angle in lodgepole pine: a comparison of six different two-segment models. Ann. For. Sci. 69(8): 927-937. doi: 10.1007/s13595-012-0226-z.

Wang, X.P., Ross, R.J., McClellan, M., Barbour, R.J., Erickson, J.R., Forsman, J.W., and McGinnis, G.D. 2001. Nondestructive evaluation of standing trees with a stress wave method. Wood Fiber Sci. 33(4): 522-533.

Weissenberg, K. 1972. Experiences of lodgepole pine in Finland. In meeting of the Nordic working group on provenance research and seed procurement, August 1972, Varparanta. pp. 15-19.

Wu, H., Ivkovic, M., Gapare, W., Matheson, A., Baltunis, B., Powell, M., and McRae, T. 2008. Breeding for wood quality and profit in Pinus radiata: a review of genetic parameter estimates and implications for breeding and deployment. N. Z. J. For. Sci. 38(1): 56-87.

Wu, H.X., Powell, M.B., Yang, J.L., Ivković, M., and McRae, T.A. 2007. Efficiency of early selection for rotation-aged wood quality traits in radiata pine. Ann. For. Sci. 64(1): 1-9.

Wu, H.X., and Sanchez, L. 2011. Effect of selection method on genetic correlation and gain in a twotrait selection scheme. Aus. For. 74(1): 36-42.

Yanchuk, A.D., and Sanchez, L. 2011. Multivariate selection under adverse genetic correlations: impacts of population sizes and selection strategies on gains and coancestry in forest tree breeding. Tree Genet. Genomes, 7(6): 1169-1183.

Zobel, B., and Van Buijtenen, J. 1989. Wood variation: its causes and control. Springer-Verlag, Berlin. p. 363 
Table 1. Description of the two lodgepole pine progeny trials and sampling details for growth and

wood quality traits

\begin{tabular}{lcc}
\hline Trial & Övra & Lagfors \\
\hline Latitude & $63^{\circ} 57^{\prime} \mathrm{N}$ & $62^{\circ} 45^{\prime} \mathrm{N}$ \\
Longitude & $16^{\circ} 46^{\prime} \mathrm{E}$ & $17^{\circ} 08 \mathrm{E}$ \\
Elevation $(\mathrm{m})$ & 350 & 220 \\
Annual rainfall $(\mathrm{mm})$ & 669 & 677 \\
Soil type & Sandy-silty moraine & Sandy moraine \\
Planting year & 1980 & 1979 \\
Breeding zone & 4 & 5 \\
Number of provenances & 4 & 2 \\
Total number of families & 178 & 214 \\
Total number of sampled trees and families for DBH & $4329-178$ & $6289-214$ \\
Total number of sampled trees and families for AV & $1250-100$ & $1332-115$ \\
Total number of sampled trees and families for SilviScan & $399-100$ & $424-107$ \\
\hline
\end{tabular}


Table 2. Mean, minimum to maximum range, and phenotypic coefficient of variation $\left(\mathrm{CV}_{\mathrm{p}}\right)$ for pith to bark core wood properties in two lodgepole pine trials

\begin{tabular}{|c|c|c|c|c|c|c|}
\hline \multirow[t]{3}{*}{ Variables } & \multicolumn{6}{|c|}{ Trial } \\
\hline & \multicolumn{3}{|c|}{ Övra } & \multicolumn{3}{|c|}{ Lagfors } \\
\hline & Mean & Min-max & $C V_{p}(\%)$ & Mean & Min-max & $\mathrm{CV}_{\mathrm{p}}(\%)$ \\
\hline Core length $(\mathrm{mm})$ & 136.1 & $72-218$ & 18.49 & 125.6 & $77-205$ & 15.5 \\
\hline $\mathrm{DBH}(\mathrm{mm})$ & 130.5 & $30-232.5$ & 24.47 & 128.1 & $40-250$ & 21.65 \\
\hline Ring Width (mm) & 2.47 & $1.39-4.43$ & 18.12 & 2.42 & $1.57-3.69$ & 15.1 \\
\hline EWP (\%) & 51.79 & $31.23-68.07$ & 10.5 & 50.66 & $38.42-64.78$ & 8.48 \\
\hline TWP (\%) & 30.83 & $20.32-50.4$ & 15.57 & 29.44 & $20.06-40.65$ & 11.84 \\
\hline LWP (\%) & 17.38 & $9.84-28.09$ & 16.55 & 19.9 & $12.73-28.67$ & 14.01 \\
\hline $\operatorname{DEN}\left(\mathrm{kg} / \mathrm{m}^{3}\right)$ & 456.6 & $365.8-582.1$ & 8.11 & 483.2 & $385.9-570.7$ & 6.98 \\
\hline $\operatorname{EWD}\left(\mathrm{kg} / \mathrm{m}^{3}\right)$ & 343.2 & $286.6-431.6$ & 7.19 & 357.2 & $279.2-426.9$ & 6.14 \\
\hline $\operatorname{TWD}\left(\mathrm{kg} / \mathrm{m}^{3}\right)$ & 499.8 & 409.6-591.2 & 6.75 & 520.2 & $431.5-612.8$ & 5.87 \\
\hline $\operatorname{LWD}\left(\mathrm{kg} / \mathrm{m}^{3}\right)$ & 735.8 & $603.7-870.2$ & 6.9 & 774.4 & $632.6-914.3$ & 6.32 \\
\hline $\mathrm{MOE}_{\mathrm{s}}$ (Gpa) & 10.42 & $4.66-17.50$ & 20.99 & 11.96 & $6.83-16.75$ & 15.71 \\
\hline $\operatorname{MFA}\left({ }^{\circ}\right)$ & 18.6 & $8.20-36.41$ & 27.89 & 16.62 & $8.20-29.40$ & 23.8 \\
\hline $\mathrm{MOE}_{\text {tof }}(\mathrm{Gpa})$ & 13.69 & $5.53-21$ & 17.11 & 15.93 & $9.22-25.64$ & 15.08 \\
\hline
\end{tabular}

Note : $D B H$ diameter at breast height, $E W P$ earlywood width proportion, $T W P$ transition wood width proportion, $L W P$ latewood width proportion, $D E N$ area-weighted mean wood density, $E W D$ area-weighted earlywood density, TWD area-weighted transition wood density, $L W D$ area-weighted latewood density, $M F A$ microfibril angle, $M O E_{s}$ modulus of elasticity estimated using SilviScan, $M O E_{\text {tof }}$ modulus of elasticity estimated using acoustic velocity and constant green density 
Table 3. Additive genetic (above diagonal) and phenotypic (below diagonal) correlations between growth and wood quality traits in two progeny trials of lodgepole pine

Narrow-sense heritability estimates of traits are shown on the diagonal of the table (standard errors within the parentheses)

Övra

\begin{tabular}{|c|c|c|c|c|c|c|c|c|c|c|c|}
\hline & \multicolumn{4}{|c|}{ Growth traits } & \multicolumn{7}{|c|}{ Wood quality traits } \\
\hline & DBH & EWP & TWP & LWP & Density & EWD & TWD & LWD & MFA & $\mathrm{MOE}_{\mathrm{s}}$ & $\mathrm{MOE}_{\text {tof }}$ \\
\hline DBH & $0.10(0.04)$ & $-0.36(0.23)$ & $0.67(0.18)$ & $-0.37(0.15)$ & $-0.24(0.23)$ & $-0.53(0.25)$ & $-0.14(0.24)$ & $-0.06(0.25)$ & $0.80(0.61)$ & $-0.51(0.26)$ & $-0.35(0.20)$ \\
\hline EWP & $-0.09(0.05)$ & $0.17(0.20)$ & $-0.72(0.15)$ & $-0.32(0.27)$ & $-0.67(0.18)$ & $-0.60(0.24)$ & $-0.46(0.26)$ & $-0.28(0.32)$ & $-0.18(0.35)$ & $-0.42(0.48)$ & $-0.45(0.29)$ \\
\hline TWP & $0.41(0.04)$ & $-0.85(0.01)$ & $0.47(0.21)$ & $-0.32(0.24)$ & $0.15(0.24)$ & $0.24(0.25)$ & $0.02(0.25)$ & $-0.12(0.26)$ & $0.07(0.33)$ & $0.05(0.38)$ & $0.30(0.25)$ \\
\hline LWP & $-0.50(0.04)$ & $-0.48(0.04)$ & $-0.07(0.05)$ & $0.40(0.22)$ & $0.71(0.12)$ & $0.48(0.18)$ & $0.55(0.17)$ & $0.48(0.20)$ & $0.14(0.29)$ & $0.43(0.26)$ & $0.26(0.28)$ \\
\hline Density & $-0.26(0.05)$ & $-0.50(0.04)$ & $0.20(0.05)$ & $0.62(0.03)$ & $0.29(0.22)$ & $0.89(0.05)$ & $0.99(0.03)$ & $0.90(0.09)$ & $0.04(0.29)$ & $0.65(0.27)$ & $0.46(0.25)$ \\
\hline EWD & $-0.29(0.05)$ & $-0.33(0.04)$ & $0.11(0.05)$ & $0.43(0.04)$ & $0.87(0.01)$ & $0.33(0.22)$ & $0.92(0.08)$ & $0.63(0.17)$ & $0.07(0.31)$ & $0.51(0.29)$ & $0.42(0.28)$ \\
\hline TWD & $-0.17(0.05)$ & $-0.24(0.05)$ & $0.04(0.05)$ & $0.38(0.04)$ & $0.90(0.01)$ & $0.77(0.02)$ & $0.42(0.23)$ & $0.96(0.04)$ & $-0.02(0.30)$ & $0.67(0.29)$ & $0.36(0.26)$ \\
\hline LWD & $-0.17(0.05)$ & $0.02(0.05)$ & $-0.18(0.05)$ & $0.26(0.05)$ & $0.75(0.02)$ & $0.59(0.03)$ & $0.87(0.01)$ & $0.40(0.23)$ & $-0.04(0.30)$ & $0.52(0.25)$ & $0.23(0.27)$ \\
\hline MFA & $0.19(0.05)$ & $-0.40(0.04)$ & $0.48(0.04)$ & $-0.05(0.05)$ & $0.06(0.05)$ & $0.03(0.05)$ & $0.03(0.05)$ & $-0.16(0.05)$ & $0.30(0.20)$ & $-0.75(0.16)$ & $-0.67(0.28)$ \\
\hline $\mathrm{MOE}_{\mathrm{s}}$ & $-0.28(0.05)$ & $0.17(0.05)$ & $-0.37(0.04)$ & $0.31(0.05)$ & $0.34(0.04)$ & $0.32(0.05)$ & $0.32(0.04)$ & $0.45(0.04)$ & $-0.88(0.01)$ & $0.30(0.20)$ & $0.91(0.30)$ \\
\hline $\mathrm{MOE}_{\text {tof }}$ & $-0.20(0.03)$ & $0.03(0.05)$ & $-0.15(0.05)$ & $0.20(0.05)$ & $0.25(0.05)$ & $0.24(0.05)$ & $0.21(0.05)$ & $0.24(0.05)$ & $-0.59(0.03)$ & $0.67(0.03)$ & $0.20(0.09)$ \\
\hline \multicolumn{12}{|c|}{ Lagfors } \\
\hline & \multicolumn{4}{|c|}{ Growth traits } & \multicolumn{7}{|c|}{ Wood quality traits } \\
\hline & $\mathrm{DBH}$ & EWP & TWP & LWP & Density & EWD & TWD & LWD & MFA & $\mathrm{MOE}_{\mathrm{s}}$ & $\mathrm{MOE}_{\text {tof }}$ \\
\hline$\overline{\text { DBH }}$ & $0.12(0.04)$ & $-0.34(0.17)$ & $0.45(0.17)$ & $0.03(0.19)$ & $-0.31(0.22)$ & $-0.48(0.20)$ & $-0.49(0.26)$ & $-0.68(0.22)$ & $0.35(0.33)$ & $-0.80(0.53)$ & $-0.14(0.20)$ \\
\hline EWP & $-0.03(0.05)$ & $0.64(0.21)$ & $-0.93(0.15)$ & $-0.97(0.22)$ & $-0.63(0.15)$ & $-0.43(0.18)$ & $-0.41(0.23)$ & $0.05(0.25)$ & $-0.96(0.22)$ & $0.55(0.52)$ & $-0.34(0.18)$ \\
\hline TWP & $0.41(0.04)$ & $-0.76(0.02)$ & $0.30(0.20)$ & $0.39(0.34)$ & $0.44(0.27)$ & $0.39(0.28)$ & $0.14(0.33)$ & $-0.31(0.33)$ & $0.67(0.27)$ & $-0.37(0.46)$ & $0.33(0.23)$ \\
\hline LWP & $-0.47(0.04)$ & $-0.57(0.03)$ & $-0.07(0.05)$ & $0.48(0.21)$ & $0.73(0.16)$ & $0.35(0.21)$ & $0.62(0.23)$ & $0.21(0.29)$ & $0.90(0.37)$ & $-0.26(0.56)$ & $0.28(0.28)$ \\
\hline Density & $-0.35(0.04)$ & $-0.49(0.04)$ & $0.09(0.05)$ & $0.63(0.03)$ & $0.66(0.21)$ & $0.94(0.04)$ & $0.96(0.03)$ & $0.73(0.11)$ & $0.50(0.33)$ & $0.29(0.35)$ & $0.62(0.17)$ \\
\hline EWD & $-0.42(0.04)$ & $-0.27(0.05)$ & $0.00(0.05)$ & $0.42(0.04)$ & $0.87(0.01)$ & $0.76(0.22)$ & $0.93(0.06)$ & $0.76(0.13)$ & $0.61(0.38)$ & $0.39(0.32)$ & $0.56(0.18)$ \\
\hline TWD & $-0.24(0.05)$ & $-0.23(0.05)$ & $-0.03(0.05)$ & $0.38(0.04)$ & $0.90(0.00)$ & $0.81(0.02)$ & $0.46(0.20)$ & $0.88(0.07)$ & $0.54(0.44)$ & $0.47(0.36)$ & $0.65(0.21)$ \\
\hline LWD & $-0.35(0.04)$ & $0.03(0.05)$ & $-0.25(0.04)$ & $0.28(0.04)$ & $0.78(0.02)$ & $0.66(0.03)$ & $0.86(0.01)$ & $0.39(0.20)$ & $0.25(0.43)$ & $0.53(0.32)$ & $0.49(0.21)$ \\
\hline MFA & $0.19(0.05)$ & $-0.33(0.04)$ & $0.40(0.04)$ & $0.00(0.00)$ & $-0.12(0.05)$ & $-0.13(0.05)$ & $-0.18(0.05)$ & $-0.37(0.04)$ & $0.33(0.19)$ & $-0.68(0.26)$ & $-0.43(0.25)$ \\
\hline $\mathrm{MOE}_{\mathrm{s}}$ & $-0.32(0.05)$ & $0.06(0.05)$ & $-0.30(0.04)$ & $0.28(0.04)$ & $0.54(0.03)$ & $0.49(0.04)$ & $0.53(0.03)$ & $0.64(0.03)$ & $-0.87(0.01)$ & $0.13(0.16)$ & $0.90(0.30)$ \\
\hline $\mathrm{MOE}_{\text {tof }}$ & $-0.05(0.03)$ & $-0.12(0.05)$ & $-0.05(0.05)$ & $0.24(0.04)$ & $0.43(0.04)$ & $0.38(0.04)$ & $0.40(0.04)$ & $0.39(0.04)$ & $-0.46(0.04)$ & $0.61(0.03)$ & $0.29(0.10)$ \\
\hline
\end{tabular}


Note Table 3. $D B H$ diameter at breast height, $E W P$ earlywood width proportion, $T W P$ transition wood width proportion, $L W P$ latewood width proportion, $D E N$ area-weighted mean wood density, $E W D$ area-weighted earlywood density, $T W D$ areaweighted transition wood density, $L W D$ area-weighted latewood density, $M F A$ microfibril angle, $M O E_{s}$ modulus of elasticity estimated using SilviScan, $M O E_{\text {tof }}$ modulus of elasticity estimated using acoustic velocity and constant green density

Table 4. Genetic gains and correlated genetic responses for $\mathrm{DBH}, \mathrm{MOE}_{\mathrm{s}}$ and $\mathrm{MOE}_{\mathrm{tof}}$ at

Övra and Lagfors. Bold, genetic gain; normal, genetic response

\begin{tabular}{llll}
\hline \multirow{2}{*}{ Selection trait } & \multicolumn{3}{c}{ Response (\%) } \\
\cline { 2 - 4 } & $\mathrm{DBH}$ & $\mathrm{MOE}_{\mathrm{s}}$ & $\mathrm{MOE}_{\text {tof }}$ \\
\hline $\mathrm{DBH}$ & $\mathbf{7 . 9}$ & -5.5 & -2.3 \\
$\mathrm{MFA}$ & 4.5 & -9.6 & -8.0 \\
$\mathrm{MOE}_{\mathrm{s}}$ & -6.5 & $\mathbf{1 3 . 0}$ & 11.4 \\
$\mathrm{MOE}_{\text {tof }}$ & -3.0 & 12.5 & $\mathbf{1 2 . 7}$ \\
\hline
\end{tabular}

Note: $D B H$ Diameter at breast height, $M F A$ microfibril angle

$M O E_{s}$ modulus of elasticity from SilviScan

$M O E_{t o f}$ modulus of elasticity from acoustic velocity 


\section{Figure Captions}

Fig. 1 Phenotypic trends for mean a) ring width b) wood density c) MFA, d) MOE, e) Earlywood proportion and f) Latewood proportion from cambial age 1 to 26 at breast height for two trials of lodgepole pine

Fig.2 Narrow-sense heritability trends for a) cumulative ring width, b) wood density, c) MFA and d) MOE from cambial age 1 to 26 at breast height, based on area-weighted values, for the two trials of lodgepole pine

Fig. 3 Age-age genetic correlation between earlier ages and the reference age of 26 years in wood properties for a) cumulative ring width, b) wood density, c) MFA and d) MOE from cambial age 1 to 26 at breast height, based on area-weighted values, for the two trials of lodgepole pine

Fig. 4 Efficiency of early selection between earlier ages and the reference age of 26 years in wood properties for a) cumulative ring width, b) wood density, c) MFA and d) MOE from cambial age 1 to 26 at breast height, based on area-weighted values, for the two trials of lodgepole pine 


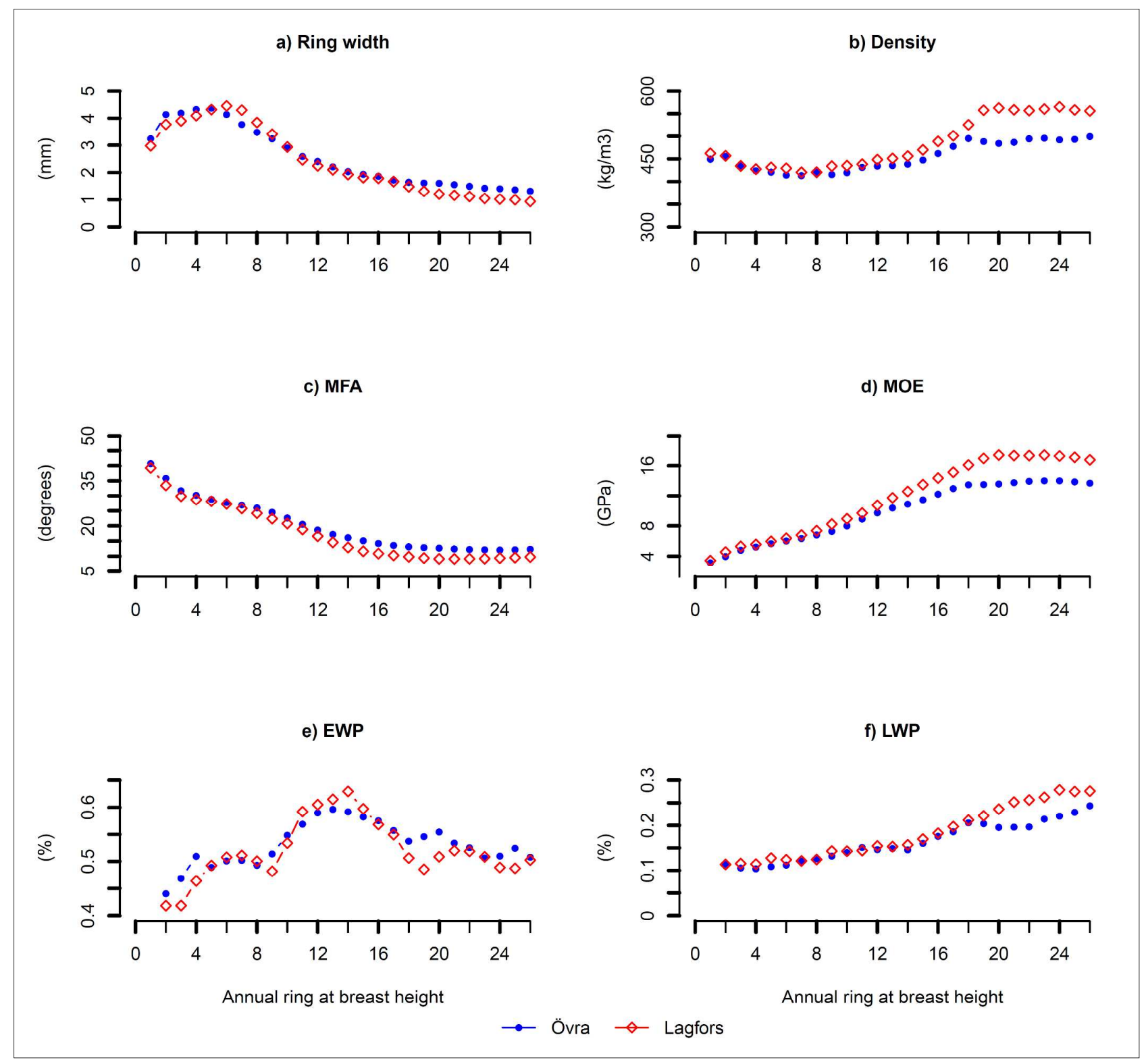

Fig.1 
a) Cumulative ring width

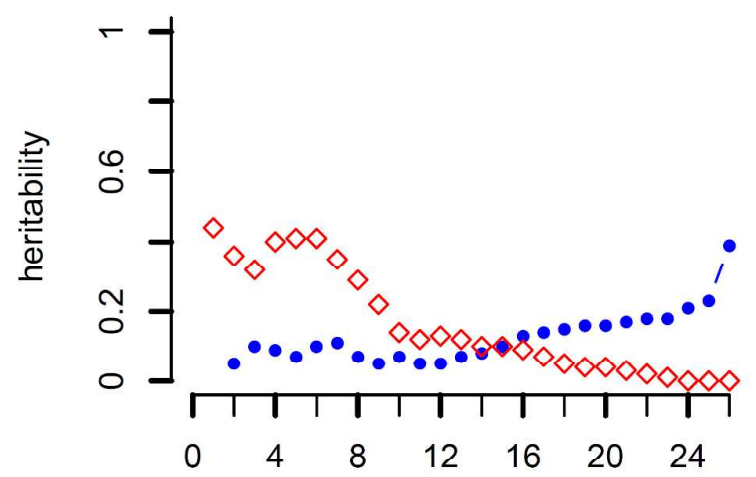

c) Area-weighted MFA

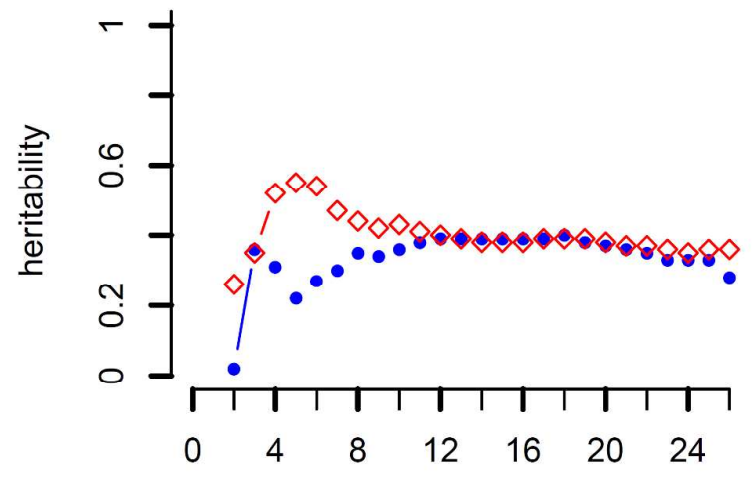

Annual ring at breast height b) Area-weighted Density

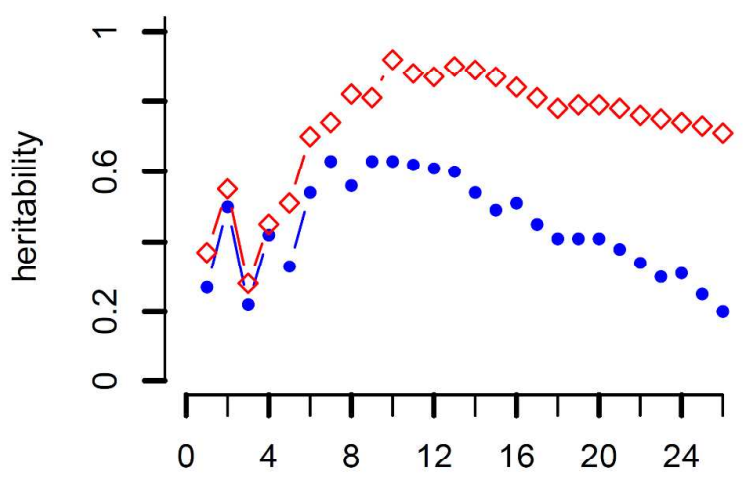

d) Area-weighted MOE

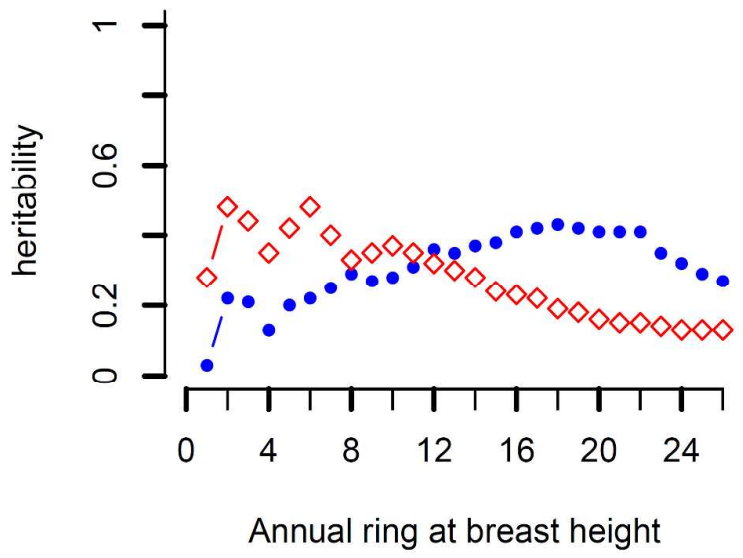

Annual ring at breast height

$\multimap$ Övra $\diamond$ Lagfors

Fig.2 


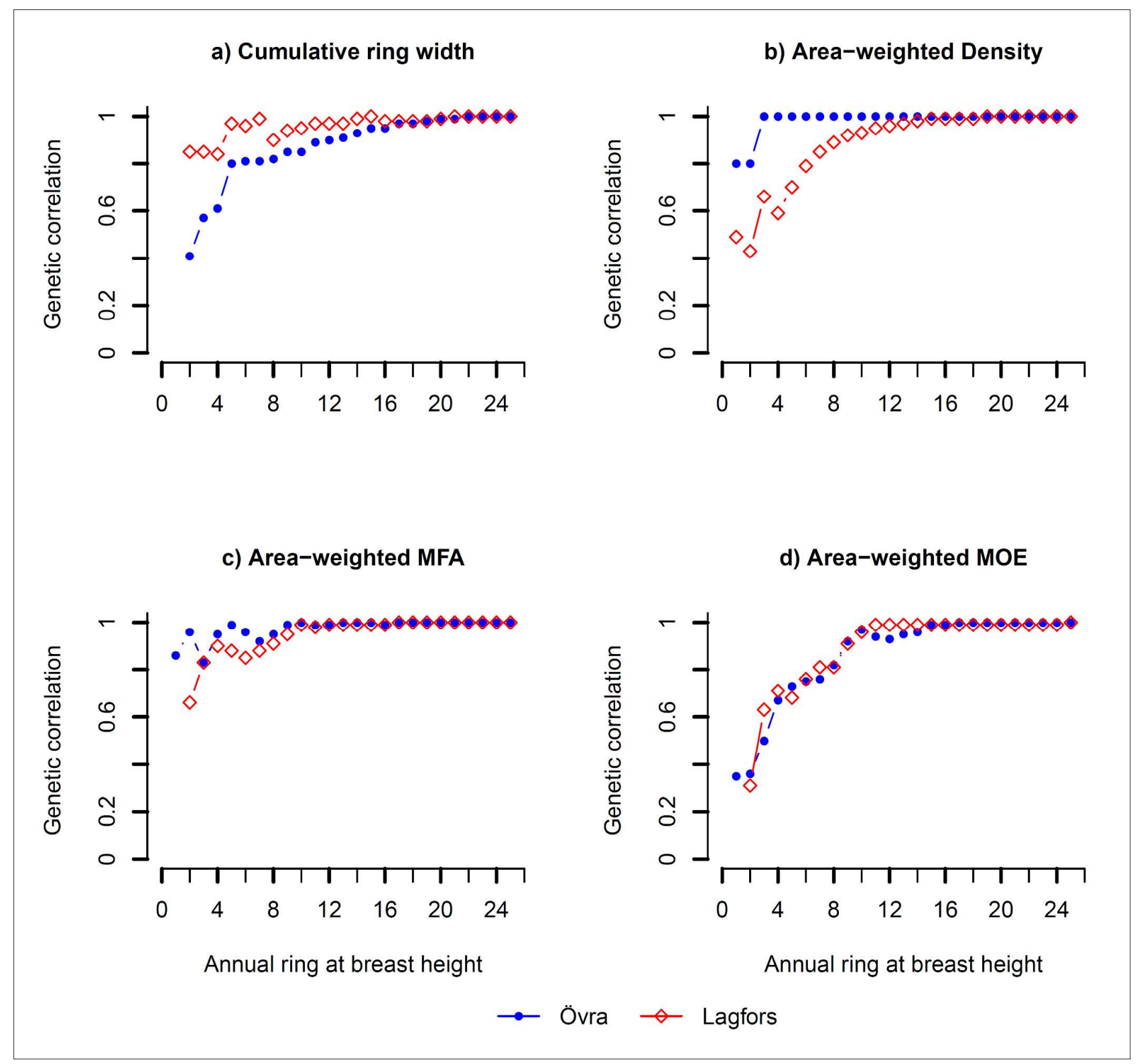

Fig.3 
a) Cumulative ring width

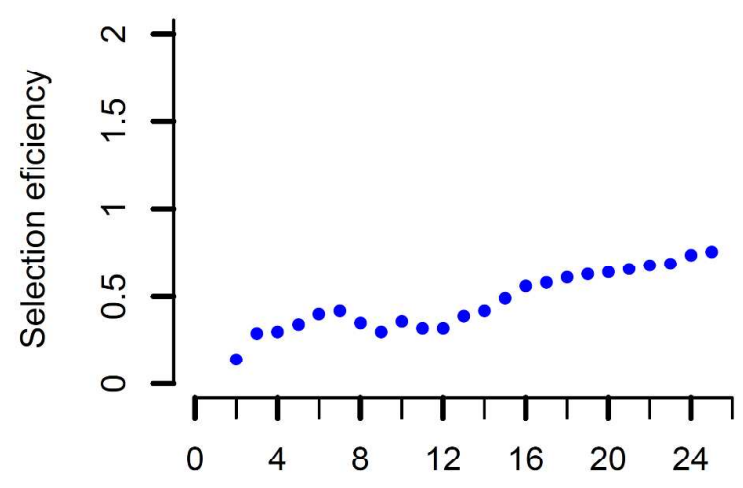

c) Area-weighted MFA

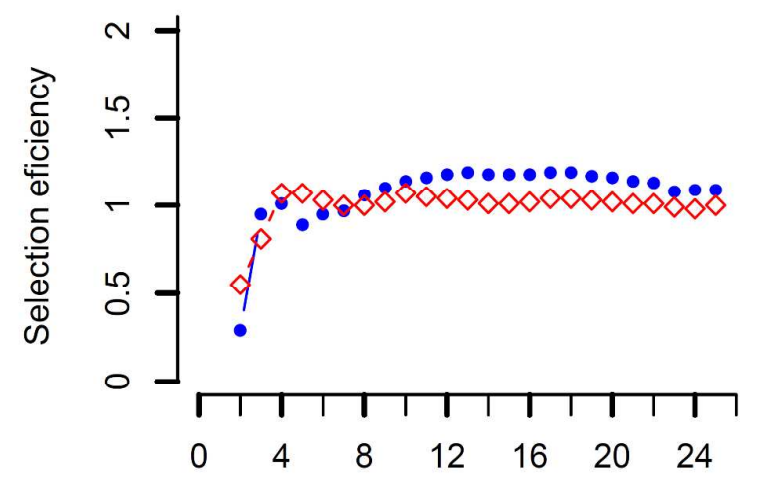

Annual ring at breast height b) Area-weighted Density

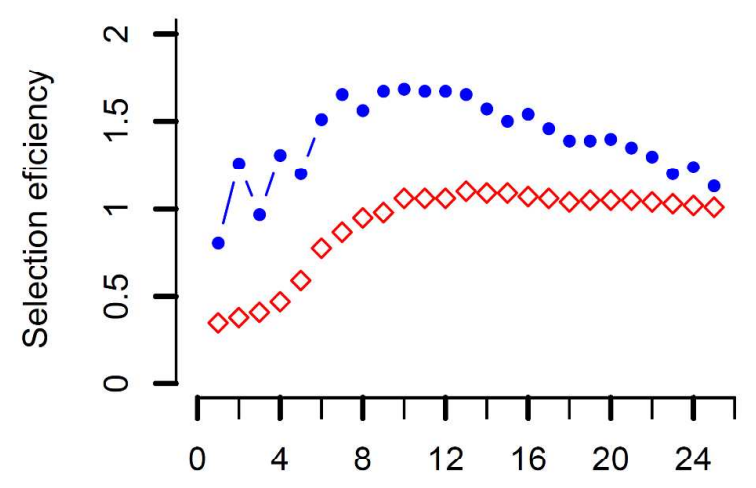

d) Area-weighted MOE

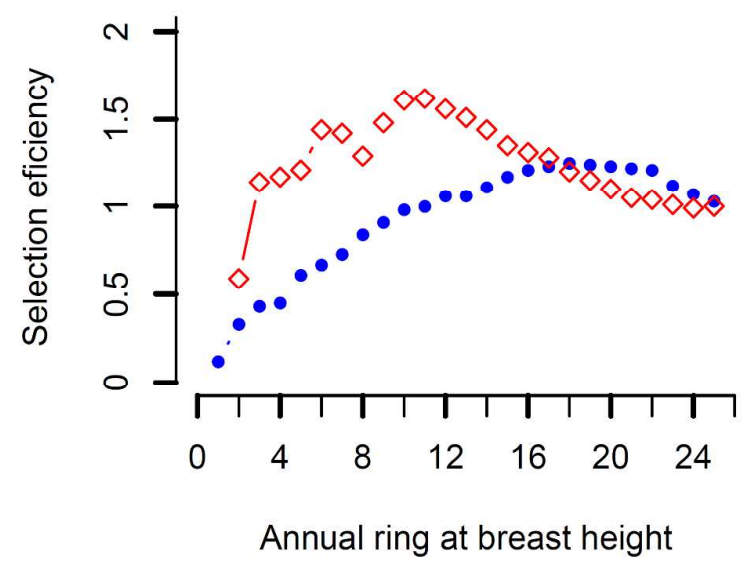

\section{$\rightarrow$ Övra $\neg$ Lagfors}

Fig.4 